\title{
Relationship of Alkaline Stress and Acute Copper Toxicity in the Snail Goniobasis livescens (Menke)
}

\author{
P. C. Paulson, ${ }^{1}$ J. R. Pratt ${ }^{2}$, and J. Cairns, Jr. ${ }^{2, *}$ \\ ${ }^{1}$ School of Public Health, University of Michigan, Ann Arbor, MI 48109, and \\ 2University Center for Environmental Studies, and Department of Biology, \\ Virginia Polytechnic Institute and State University, Blackburg, VA 24061
}

Organism response to toxic compounds is routinely tested in highly controlled laboratory tests conducted under rigorous standards (AMERICAN PUBLIC HEALTH ASSOCIATION [APHA] et al. 1976, AMERICAN SOCIETY FOR TESTING AND MATERIALS, 1980). Toxicants are rarely present in nature in singular doses, and stresses on particular organisms may come from a variety of natural and anthropogenic sources. A number of studies have shown alteration of responses to toxicants as a result of multiple assaults (CAIRNS et al. 1975) or prior stress (CAIRNS et a1. 1976). The purpose of this study was to evaluate the effect of prior sublethal stress (in this case, alkaline $\mathrm{pH}$ ) on the subsequent toxicity of copper. The initial hypothesis was that elevated $\mathrm{pH}$ stress would increase susceptibility of test organisms to copper toxicity. Although $\mathrm{pH}$ excursions into acid ranges have normaliy attracted attention, industrial process waters commonly range to $\mathrm{pH} 11.7$ (USEPA 1976). Excursions to $\mathrm{pH}$ above 7 may also increase the relative toxicity of other compounds, e.g., ammonia (EUROPEAN INLAND FISHERIES ADVISORY COMMISSION 1979).

\section{MATERIALS AND METHODS}

This study was carried out during the summer term of the University of Michigan Biological Station at Douglas Lake, which is a well-buffered, hardwater, mesotrophic lake. All testing was done in untreated lake water.

The organism selected for study was the snail Goniobasis livescens (Menke) (Pleurocercidae), which is widely distributed from New York west through the Great Lakes and from Canada south to the Ohio River (BAKER 1928). Goniobasis livescens occurs in a wide variety of lentic and lotic habitats and is common in hard waters with rocky or sandy bottoms. The organism was chosen because it is (1) easily obtainable, (2) relatively sessile and incapable of gross avoidance responses, and (3) intermediate in the food chain.

*orrespondence and offprint requests. 
Approximately $150 \mathrm{G}$. Iivescens were collected from Douglas Lake in JuIy 1982. These snails were returned to the laboratory and acclimated to constant temperature for $24 \mathrm{hr}$ prior to testing.

Acclimated snails were randomly separated into two groups. One group (stressed) was placed in $3 \mathrm{~L}$ of alkalinized lake water that had been adjusted to $\mathrm{pH} 10.5$ using $\mathrm{NaOH}$. The second group (unstressed) was transferred to $3 \mathrm{~L}$ of Douglas Lake water ( $\mathrm{pH} 8.5$ ). The two groups remained in these containers for $24 \mathrm{hr}$. Containers for this part of the study and all subsequent toxicity tests were glass battery jars that had been previously detergent washed and then rinsed in acid $\left(10 \% \mathrm{H}_{2} \mathrm{SO}_{4}\right)$ and then distilled water. Tests were run at constant temperature by placing test containers in a flow-through water bath at $14-16^{\circ} \mathrm{C}$.

Snails were removed from the alkaline stress after $24 \mathrm{hr}$ and rinsed to remove any alkaline solution. Stressed and unstressed snails were then randomly placed in test containers that contained $2 \mathrm{~L}$ of toxicant solution for completion of a 96-hr acute toxicity test following standard methods (APHA et al. 1976). Toxicant solutions were made using a $1000 \mathrm{ppm}$ stock solution of copper ( $\mathrm{Cu}^{+}$) made by dissolving the appropriate amount of $\mathrm{CuSO}_{4} \cdot 5 \mathrm{H}_{2} \mathrm{O}$ and bringing the volume to $1 \mathrm{~L}$ in a volumetric flask. Test concentrations were selected based on a series of previous screening tests. Tests concentrations used were 0 (contro1) $, 0.31,0.54,0.96,1.7,3.1$, and $5.4 \mathrm{ppm} \mathrm{Cu}$. Ten snails were placed in each test container that was not aerated. They were not fed. Test water was monitored daily for $\mathrm{pH}$, dissolved oxygen, hardness, and temperature. Water samples were removed from each test container after $96 \mathrm{hr}$ for determination of final copper concentrations. Samples were filtered through $0.45 \mu \mathrm{m}$ filters and acidified with nitric acid. Samples of Douglas Lake water were taken for determination of background copper concentrations, and the $1000 \mathrm{ppm}$ copper stock solution was analyzed. All sample concentrations were determined by atomic absorption spectrophotometry according to standard methods (APHA et al. 1976).

Mortality was determined by prodding the foot of each test organism with a probe and noting any reaction. Animals not responding were placed in lake water for 15 min to check for revival. Snails not reviving in 15 min were classified as dead. Mortality was recorded daily. Revived snails were returned to test containers.

After noting differences in sloughed mucus between test concentrations, evaluation of the quantity of sloughed mucus was begun using a grid drawn on a plastic transparency that was the same size as the bottom of the 
test container. Amount of mucus was rated on a 5 point scale ( 1 minimum), and the color of the mucus was recorded. If categorization became difficult, halfpoints were assigned.

Results of acute toxicity tests were analyzed by probit analysis to determine LC50s for the two groups (HELWIG \& COUNCIL 1979, DAUM 1970, FINNEY 1968). Comparison of relative effect of alkaline stress and no prior stress was made according to DAUM (1970). Comparison of groups for final copper concentrations, mortality, and mucus ratings were done according to a non-parametric two-way layout design adapted from Friedman (HOLLANDER \& WOLFE

1973). Mucus production and test concentration were correlated using Kendall's tau (HOLLANDER \& WOLFE 1973).

\section{RESULTS AND DISCUSSION}

No mortality was recorded in snails receiving the 24-hr alkaline stress. However, when test organisms were removed for random distribution into test containers, only $4 \%$ of the snails in $\mathrm{pH} 10.5$ water were in motion while $42 \%$. were observed actively moving in the untreated water.

Mortality in the entire group of stressed snails was lower than in the unstressed group (Friedman's $\mathrm{S}=3.42, \mathrm{p}=0.07$ ), although the significance level is not high. Probit analysis of acute toxicity test results indicate a significantly higher LC50 in the stressed group than unstressed (Figure 1 and TABLE 1) $(\mathrm{p}<0.05)$. Differences could not be directly attributed to differences in water quality in test containers. Water quality was quite stable (TABLE 2), and only controls had low levels of dissolved oxygen $(<5 \mathrm{ppm})$ at the end of the test (range= 3.6-4.1). There were no control deaths. Al1 other values had acceptable ranges of variation of the most commonly monitored parameters.

All final copper concentrations were below nominal values (except controls; TABLE 3). Sma11 background levels of copper were detected in lake water (up to 0:017 ppm $\mathrm{Cu}$ ). Reductions of measurable copper levels increased with concentrations in both test groups, and final and average concentrations were not significantly different between the two groups. The reason(s) for decreasing copper concentrations are unknown.

Mucus production and sloughing were noticeably different in the stressed and unstressed groups (TABLE 3). Production of sloughed mucus was significantly greater in the stressed group (Friedman's $S=6.86, p<0.001$ ). Mucus production increased with increasing test concentration in both groups (Kenda11's tau=0.67, $\mathrm{p}=0.001$ ). This 


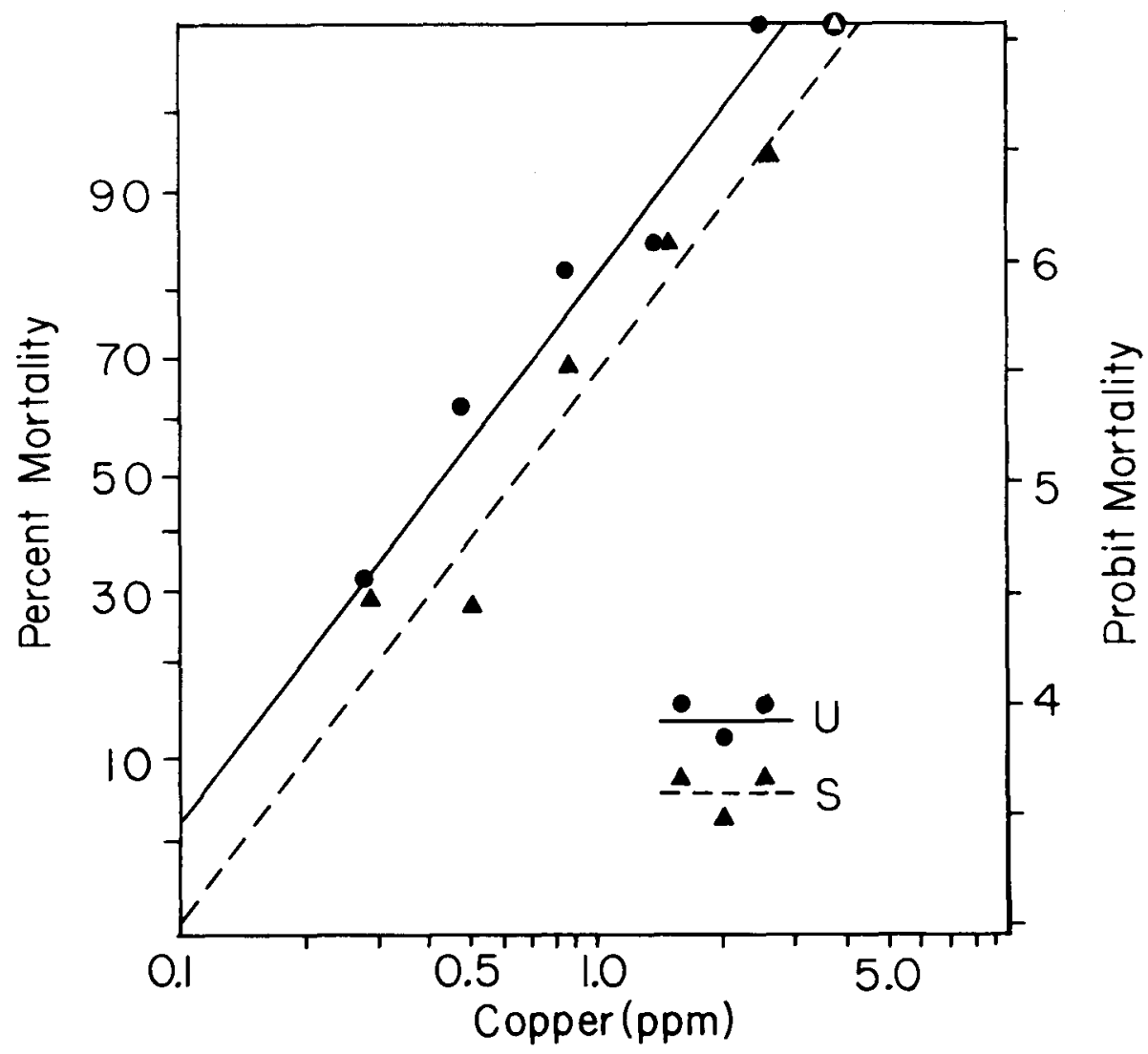

Figure 1. Acute toxicity of copper to alkaline stressed (S) and unstressed (U) snails, Goniobasis livescens (Menke). Plot based on average copper concentration in test chambers.

significant correlation suggests that the amount of mucus produced might be related to toxicant stress. Mucus produced in test containers was generally white, but that sloughed by control animals appeared brown. Mucus production tended to be lower than controls in low test concentrations and approached control ratings only in the highest concentrations.

The LC50 values determined for both groups of test organisms fall near the range of values determined for other species. For example, LC50s determined from nominal concentrations in this study were 0.44 and $0.65 \mathrm{ppm} \mathrm{Cu}$ for the unstressed and stressed groups, respectively. Values previously determined for similar hardness and temperature conditions include $0.43 \mathrm{ppm} \mathrm{Cu}$ for fathead minnow Pimephales promelas (MOUNT 1968), and 0.33 for the blacknose dace Rhinichthys atratulus (NWQL cited in 
Table 1. LC50 values for copper for alkaline stressed and unstressed groups. Values expressed as ppm $\mathrm{Cu}$.

\begin{tabular}{|c|c|c|c|}
\hline Group & $\begin{array}{l}\text { Nominal Cu } \\
\text { LC50 } \\
(\mathrm{FL})^{\mathrm{a}}\end{array}$ & $\begin{array}{l}\text { Average } \mathrm{Cu} \\
\text { LC50 } \\
\text { (FL) }\end{array}$ & $\begin{array}{c}\text { Regression Slope } \\
\text { for Average } \mathrm{Cu} \\
(95 \% \mathrm{CI})\end{array}$ \\
\hline STRESSED & $\begin{array}{c}0.65 \\
(0.51-0.81)\end{array}$ & $\begin{array}{c}0.59 \\
(0.47-0.72)\end{array}$ & $\begin{array}{c}2.62 \\
(1.91-3.33)\end{array}$ \\
\hline UNSTRESSED & $\begin{array}{c}0.44 \\
(0.3 i-0.55)\end{array}$ & $\begin{array}{c}0.39 \\
(0.29-0.49)\end{array}$ & $\begin{array}{c}2.49 \\
(1.68-3.29)\end{array}$ \\
\hline
\end{tabular}

Table 2. Range of water quality measures in test chambers.

\begin{tabular}{lcc}
\hline Parameter & Norma 1 & Range \\
\hline Temperature & $15^{\circ} \mathrm{C}$ & $13-16$ \\
$\mathrm{pH}$ & 8.5 & $7.5-8.5$ \\
Dissolved $0_{2}$ & $5-6 \mathrm{mg} / \mathrm{L}$ & $3.6-9.1^{\mathrm{a}}$ \\
Hardness & $154 \mathrm{CaCO}_{3} \mathrm{mg} / \mathrm{L}$ & --- \\
\hline
\end{tabular}

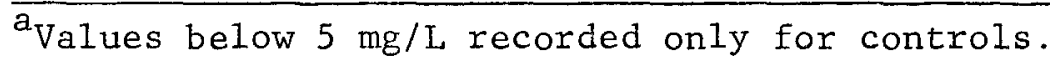

USEPA 1976). The expected response range would likely be lower in softer waters (HOWARD et a1. 1964). The elevated $\mathrm{pH}$ used as prior stress appeared to be adequately sublethal since a noticeable reduction in locomotion in the stressed group occurred but no subsequent deaths in stressed controls occurred.

Mucus secretion was significantly elevated in the stressed test group according to the subjective rating scale. Although the apparent elevation of mucus secretion and sloughing was not related to any difference between stressed and unstressed groups in terms of removal of toxicant from test containers, increased mucus production did appear to be directly related to the difference in LC50 between the two groups. This was interpreted as a simple shift in susceptibility to the toxicant (Figure 1). 


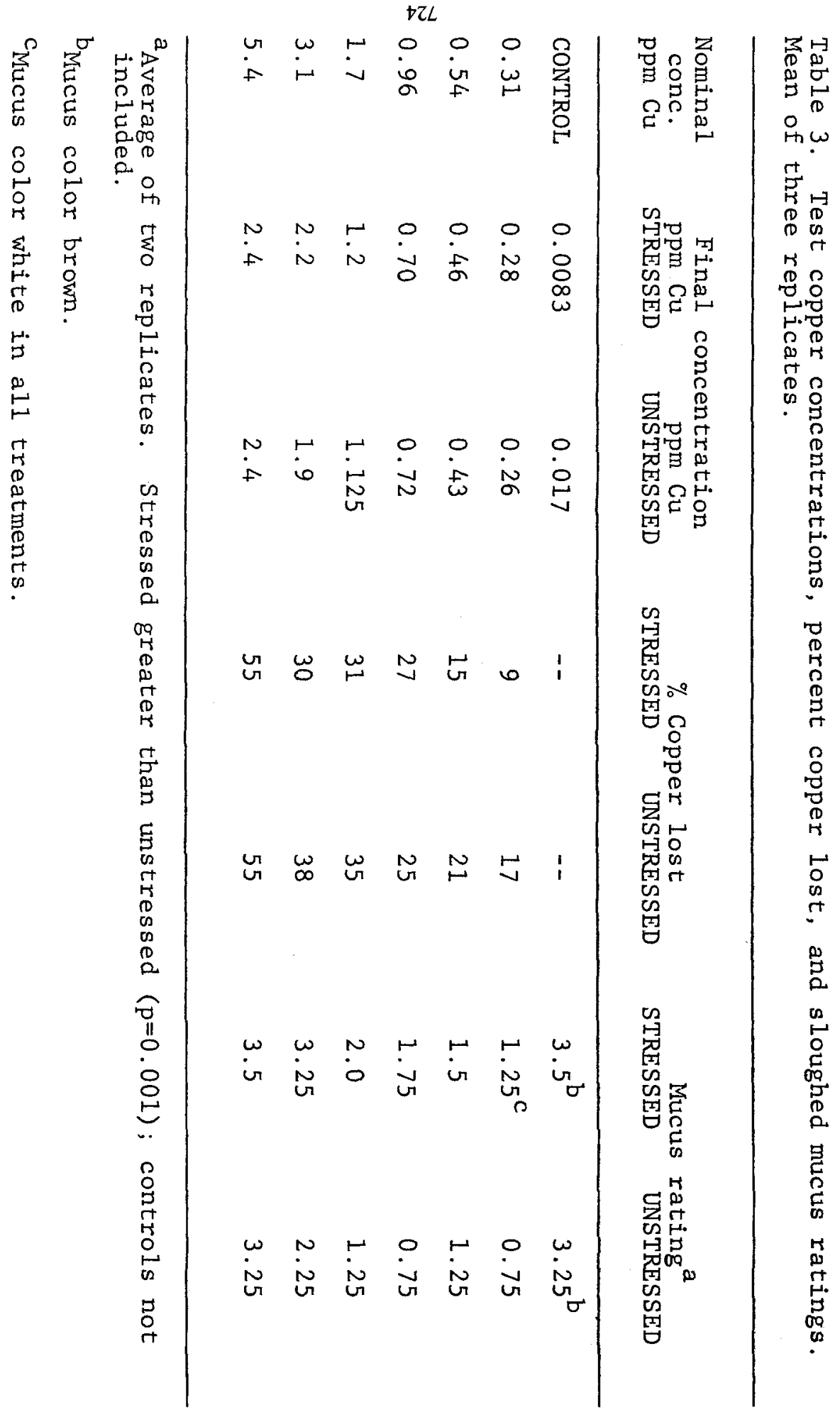


Snails previously stressed by alkaline pH appear to have some predisposed protection. This protection probably was directly attributable to increased mucus production based on the following: (1) snails in the stressed group had significantly lower mortality than those in the unstressed group, (2) snails in the stressed group sloughed more mucus, and (3) mucus sloughing was directly related to toxicant loss in test containers $(x=0.77$, $\mathrm{p}<0.01)$. VARANASI \& MARKEY (1978) also reported inductior of mucus secretion by cadmium and mercury in salmon. Significant quantities of metals were found in sloughed mucus.

These findings have certain implications for routine toxicity monitoring. Certain prior stresses may make test organisms less susceptible to toxicant action. Contrary to expectations, prior alkaline stress did not predispose test organisms to increased toxic effects. In fact, the reverse was true. Organisms initially stressed by high $\mathrm{pH}$ were more resistant to the toxicant than those not stressed. This is contrary to published results for other sublethal'stresses such as elevated temperature (CAIRNS et al. 1975). These tests are consistent with the doctrine of maximum challenge that suggests that stimuli acting on irritable tissue may serve to increase the threshold for further stimulation, an admittedly old idea (HEILBRUN 1952). Responses to adverse stimulation may be generalized to protection against the action of other toxicants.

Although this generalized protection may be important in amelioration of the effects of more than one toxicant, increased mucus secretion represents an increased metabolic burden on the organism. Results presented here refer only to short-term protection over the course of a 96-hr acute toxicity test. There is no reason to suppose from these data that lesser stimuli could induce a simila effect. No extrapolations can be made to the possibly increased feeding needs of organisms under heavier metabolic demands. Additionally, food organisms may be even more sensitive to low level toxicants or incapable of making the generalized response to stress evident in this test.

Acknowledgments. This investigation was conducted at the University of Michigan Biological Station, Pellston, Mich. The support of the Naturalist-Ecologist Training Program and its director, Dr. Claudia Jolls, are gratefully acknowledged. The assistance of Dr. Rebecca. Glover in conducting chemical analysis is greatly appreciated. Special thanks to Betty Higginbotham for typing the manuscript and to Darla Donald for editorial assistance. 
AMERICAN PUBLIC HEALTH ASSOCIATION, AMERICAN WATER WORKS ASSOCIATION, and WATER POLLUTION CONTROL FEDERATION: Standard Methods for the Examination of Water and Wastewater. 14th ed. Washington, D. C. 1976. AMERICAN SOCIETY FOR TESTING AND MATERIALS: Annual Book of ASTM Standards. Philadelphia, Pa. 1980.

BAKER, F. C.: The Freshwater Mollusca of Wisconsin, Part I, Gastropoda. Wisconsin Academy of Science, Arts, and Letters 1928.

CAIRNS, J., Jr., A. G. HEATH, and B. C. PARKER: J. Water Pollut. Control Fed. 47, 267 (1975).

CAIRNS, J., Jr., W. F. CALHOUN, M. J. MCGINNIS, and W. STRAKA: Water Resour. Bul1. 12, 1233 (1976).

DAUM, R. J.: Bul1. Entomol. Soc. $\overline{\mathrm{Am}} .16,10$ (1970). EUROPEAN INLAND FISHERIES ADVISORY COMMISSION: Water Res. 3,593 (1969).

FINNEY, D. J.: Statistical Methods in Biological Assay. 2nd ed. London: Charles Griffith 1968.

HEILBRUN, L. V.: An Outline of General Physiology. 3rd ed. Philadelphia, Pa.: W. B. Saunders Co. 1952.

HELWIG, J. T., and K. A. COUNCIL: SAS User's Guide. Cary, HC: SAS 1979.

HOLLANDER, M., and D. A. WOLFE: Nonparametric Statistica1 Methods. New York: John Wiley \& Sons 1973. HOWARD, R. E., H. N. HALVORSON, and C. C. WALDER: Am. J. Hyg. 80,33 (1964).

MOUNT, D. I. : Water Res. 2, 215 (1968).

UNITED STATES ENVIRONMENTAL' PROTECTION AGENCY: Quality Criteria for Water. Washington, DC 1976.

VARAiNASI, U., and D. MARKEY: Comp. Biochem. Physiol. 60C, 187 (1978).

Accepted July 12, 1983 